\title{
Ebelik Öğrencilerinin Güdülenme Düzeylerinin Mesleki Kariyer Planlarına Etkisi
}

\section{Effect of Motivation Levels of Midwifery Students on Professional Career Plans}

\author{
${ }^{1}$ Zümrüt BİLGİN, ${ }^{2}$ Melek EFE \\ ${ }^{1}$ Marmara Üniversitesi, Sağlık Bilimleri Fakültesi Ebelik Bölümü, İstanbul, Türkiye \\ ${ }^{2}$ İstanbul Pendik ̇lçe Sağlık Müdürlüğü-Çocuk Ergen Kadın Üreme Sağlığı Birimi, İstanbul, Türkiye
}

Zümrüt Bilgin: https://orcid.org/0000-0003-3984-5716

Melek Efe: https://orcid.org/0000-0002-4871-0648

ÖZ

Amaç: Araştırma, ebelik bölümü öğrencilerinin güdülenme düzeylerinin mesleki kariyer planlarına etkisinin belirlenmesi amacı ile yapılmıştır.

Materyal ve Metot: Tanımlayıcı türdeki araştırmanın örneklemini, İstanbul ilinde bir devlet üniversitenin sağlık bilimleri fakültesi ebelik bölümünde öğrenim gören 234 öğrenci oluşturmuş̧ur. Verilerin toplanmasında öğrencilerin sosyo-demograk özelliklerini içeren "Tanıtıcı Bilgi Formu" ile "Güdülenme Kaynakları ve Sorunları Ölçeği" kullanılmıştır. Veriler bilgisayarda analiz edilmiştir.

Bulgular: Çalışmada, öğrencilerin \%77,8'inin ebelik mesleğini isteyerek ve \%35,9'unun kolay iş bulma umuduyla seçtiği saptanmıştır. Öğrencilerin mezuniyetten hemen sonra \%32,9'unun kariyer olarak yüksek lisans yapmayı planladığı, \%35,9'unun sağlık hizmetlerinin birinci basamağında çalışmak istediği ve \%20,9'unun sağlık hizmetlerinin diğer alanlarında ebelik statüsü/ pozisyonunda çalışmayı düşündüğü saptanmıştır. Öğrencilerin ebelik bölümünü isteyerek seçmesi ile içsel ve dışsal güdülenmesi arasında, eğitimin kariyer planını etkileme durumu ile içsel güdülenmesi arasında anlamlı ilişki bulunmuștur $(\mathrm{p}<0,05)$.

Sonuç: Ögrrencilerin becerilerine yönelik kariyer planlamaları yapabilmeleri için danışmanlık verilmesi önerilir. Anahtar Kelimeler: Ebelik, kariyer planı, mesleki güdülenme

\begin{abstract}
Objective: The research, was carried out to determine the effect of motivation levels of midwifery students on their professional career plans.

Materials and Methods: The sampling of the descriptive study was composed of 234 students studying in the Midwifery Department of the Faculty of Health Sciences of a state university in Istanbul. The "Introductory Information Form" containing the socio-demographic characteristics of the students and the "Motivation Sources and Problems Scale" was used to collect the data. The data were analyzed on the computer.

Results: In the study, it was found that $77.8 \%$ of the students chose the midwifery profession voluntarily and $35.9 \%$ chose to find an easy job. $32.9 \%$ of students planned to pursue a master's degree as a career immediately after graduation, $35.9 \%$ of them want to work in the first step of health services, and $20.9 \%$ of them thought to work in midwifery status/position in other areas of health services. Between the internal and external motivation of students by willingly choosing midwifery department; A significant relation was found between the effect of education on career plan and the internal motivation $(\mathrm{p}<0.05)$.

Conclusion: Counseling is recommended for midwifery students to make career plans for their skills.
\end{abstract}

Keywords: Career plan, midwifery, professional motivation

Sorumlu Yazar / Corresponding Author:

Zümrüt Bilgin

Başıüyük Mah, Başıbüyük Cd. No:9, 34854 Maltepe/İstanbul

Tel: +902167775700

Gönderi Tarihi/ Received: 14/02/2020

Kabul Tarihi/ Accepted: 02/10/2020

Online Yayın Tarihi/ Published: 05/03/2021

Fax: +902167775701

E-mail: zumrutbilgin45@gmail.com

Atıf / Cited: Bilgin Z, Efe M. Ebelik Öğrencilerinin Güdülenme Düzeylerinin Mesleki Kariyer Planlarına Etkisi. Online Türk Sağlık Bilimleri Dergisi 2021;6(1):44-52. doi: 10.26453/otjhs.689406 


\section{GÍRIŞ}

Ebelik eğitimi, kuramsal ve uygulamalı eğitimden oluşan bir programıdır. Eğitimde, öğrenmenin gerçekleştirilmesini sağlayan temel kavramlardan biri güdülenmedir. Güdülenme, bireyi bir amaca yönelten, enerji veren ya da harekete geçiren, bilişsel ve duyusal boyutları da olan bir süreç olarak tanımlanmıştır. Başka tanıma göre güdülenme, davranışın uyandırılması, sürdürülmesi ve kontrolünü etkileyen içsel ve dişsal koşulların hepsini içeren bir durumdur. ${ }^{1,2}$ Güdülenme genel olarak içsel güdülenme, dışsal güdülenme ve olumsuz güdülenme olarak ifade edilmektedir. İçsel güdülenmede birey gerçekleştirilecek davranışı kendisi için gerekli gördüğü için yaparken, dışsal güdülenmede ise birey dış uyaranların önemi ve gereğine inandığı için davranışı yapmaktadır. 1,3

Öğrencilerin mesleki bilgi ve beceri kazanmaları aşamasında güdülenmeleri önemlidir. Öğrencilerin güdülenmesini olumlu ya da olumsuz yönde etkileyen çok çeşitli faktörler bulunmaktadır. Güdülenmeyi olumlu yönde etkileyen faktörler öğrencinin başarısını artırırken, olumsuz yönde etkileyen faktörler ise öğrencilerin hem başarısını hem de mesleki kariyer planlarını etkileyebilmektedir. ${ }^{3}$ Kariyer, bir bireyin elde ettiği veya edeceği eğitim, yetenek ve deneyimlerin birikimi olarak tanımlanmaktadır. Başka bir tanıma göre kariyer, bireyin yaşamında ilerleme sağlamak ve bir başarı elde edebilmek amacıyla izlediği yol ve süreç olarak ifade edilmektedir. ${ }^{4} \mathrm{Ka}-$ riyer planlaması ise, bireylerin firsat seçeneklerinin farkına varmalarını, kariyer hedeflerini belirlemelerini, istenilen hedeflere ulaşmalarını sağlayacak iş, eğitim ve diğer gelişimsel faaliyetlerini programlama sürecidir. ${ }^{5}$ Kariyer planlamasının en önemli yararlarından biri, bireylerin bilgi birikim ve deneyimlerini yeteneklerini geliştirmek için kullanabilmesidir. $^{5,6}$

Bireyler mesleki açıdan kendilerini geliştirmek için, çeşitli kariyer planları yapabilmektedir. Kariyer planı türlerinden biri bireysel kariyer planıdır. ${ }^{4} \mathrm{Bu}$ kariyer planında bireyler daha çok istihdam olanaklarını artırmak amacıyla kariyerlerini planlamaktadır. Çeşitli faktörlerin etkisi altında gerçekleşen bireysel kariyer plânlamasında ilk aşama kişinin kariyerini seçme aşamasıdır. ${ }^{7}$ Musriha ve $\mathrm{Msi}^{8}$ kariyer gelişiminde, bireysel özelliklerin, bireysel becerilerin önemli olduğunu belirtmişlerdir. Kanagaraj ve ark. ${ }^{9}$ kariyer planlamasında bireysel kariyer hedeflerinin örgütsel hedeflerle uyumlu hale getirilmesinin önemli olduğunu vurgulamışlardır.
Ebelik öğrencilerinde mesleki kariyer planları mesleki güdülenme düzeyi ile doğrudan ilişkilidir. Güdülenme düzeyi ise, öğrencilerin bireysel özellikleri, mesleği isteyerek seçme, mesleği sevme gibi faktörlerden etkilenmektedir. Ulusal ve uluslararası literatürde öğrencilerin güdülenme düzeyinin kariyer planlamasına etkisini belirleyen araştırmaya rastlanmamıştır. Araştırma, konu ile ilgili literatüre katkı ve gelecek araştırmalara kaynak sağlaması açısından yarar sağlayacaktır. Bu araştırma, ebelik bölümü öğrencilerinin güdülenme düzeylerinin mesleki kariyer planlamasına etkisi belirlemek amacıyla yapılmiştır.

\section{MATERYAL VE METOT}

Araştırmaya başlamadan girişimsel olmayan klinik araştırmalar etik kurulundan etik onay (Tarih: 13.12.2018, karar no: 60) kurum izni ve araştırmaya gönüllü katılan öğrencilerden ise, sözlü ve yazılı onamlar alınmıştır. Ayrıca Güdülenme Kaynakları ve Sorunları Ölçeği’nin geçerliği ve güvenirliğini yapan Acat ve Köşgeroğlu'ndan da yazılı izin alınmıştır. Tanımlayıcı tipte yürütülen bu araştırma, İstanbul ilinde bir devlet üniversitenin sağlık bilimleri fakültesinin ebelik bölümünde 2018- 2019 eğitim-öğretim döneminde yapılmıştır. Araştırmada örneklem seçimine gidilmemiş tüm evrene ulaşılmas1 hedeflenmiştir. Ebelik bölümüne kayıtlı ve eğitime devam eden öğrencilerin tümü (278 öğrenci) araştırmanın evrenini oluştururken, örneklemini ise, araştırmaya gönüllü katılan 234 öğrenci oluşturmuştur. Araştırmada tüm öğrencilere ulaşılması hedeflenmiş ancak, araştırma ile ilgili bilgi formlarının uygulandığı gün devamsızlık yapan, araştırmaya katılmayı kabul etmeyen öğrenciler araştırma kapsamı dişında tutulmuştur.

Veri Toplama Araçları: Araştırma verileri, "Tanıtıcı Bilgi Formu" ve "Güdülenme Kaynakları ve Sorunları Ölçeği” kullanılarak toplanmıştır.

Tanıtıcı Bilgi Formu: Araştırma verileri, araştırmac1 tarafından benzer araştırmalar ve literatür bilgileri incelenerek, öğrencilerin sosyo-demografik özelikleri (yaş, barındığı ortam vb.) mesleği seçme nedenleri, ebelik mesleği ve mesleğe ilişkin kariyer planlar1nı içeren sorulardan oluşmuştur. 3,6

Güdülenme Kaynakları ve Sorunları Ölçeği: Araştırmada kullanılan Güdülenme Kaynakları ve Sorunları Ölçeği'ini Acat ve Köşgeroğlu tarafından 2006 yılında geliştirilmiştir. Ölçek Likert tipte ve 24 maddeden oluşmaktadır. Ölçeğin içsel güdülenme, dışsal güdülenme ve olumsuz güdülenme olmak üzere üç 
alt boyutu bulunmaktadır. Ölçekte içsel ve dişsal güdülenme alt ölçeklerini oluşturan maddelerde "Hiç katılmıyorum" yanıtına 1, "Katılmıyorum" yanıtına 2, "Kararsızım" yanıtına 3, "Katılıyorum" yanıtına 4 ve "Kesinlikle katılıyorum" yanıtına 5 puan verilir. Olumsuz güdülenme alt ölçeğini oluşturan maddelerde "Hiç katılmıyorum" yanıtına 5, "Katılmıyorum" yanıtına 4, "Kararsızım” yanıtına 3, "Katılıyorum" yanıtına 2 ve "Kesinlikle katılıyorum" yanıtına 1 puan verilir. Ölçekte " $1,2,3,4,6$, $7,8,9,10,23$ ve 24 " no'lu maddeler içsel güdülenme $(\min -\max =11-55)$, “13,14, 15, 17 ve 20 " no'lu maddeler dişsal güdülenme (min-max=5-25), " 5,11 , $12,16,18,19,21$ ve 22 " no'lu maddeler olumsuz güdülenme (min-max=8-40) puanlarının elde edilmesinde kullanılır. Her alt ölçeğin puanı, alt ölçeğin maddelerinden alınan puanların aritmetik ortalaması alınarak belirlenir. Elde edilen üç alt ölçeğin puanlarının ortalaması kişinin mesleksel öğrenme güdülenmesi düzeyinin puanını oluşturur. Elde edilen puan ne kadar yüksekse güdülenme düzeyi de o kadar fazla olmaktadır. Acat ve Köşgeroğlu tarafından yapılan geçerlik güvenirlik çalışması sonucu ölçeğin Cronbach alfa katsayısı 0,82 , içsel güdülenme alt ölçeğinin 0,84, dışsal güdülenme alt ölçeğinin 0,69 , olumsuz güdülenme alt ölçeğinin Cronbach alfa katsayısı 0,69 olarak bulunmuştur. Bu çalışmada ise, ölçeğin Cronbach alfa katsayısı 0,81, içsel güdülenme alt ölçeğinin 0,88 , dişsal güdülenme alt ölçeğinin 0,71, olumsuz güdülenme alt ölçeğinin Cronbach alfa katsayısı 0,68 bulunmuştur. ${ }^{3}$

Araştırmanın Uygulanması: Çalışmaya katılmayı kabul eden öğrencilere çalışma hakkında açıklama yapılmıştır. Veriler, araştırmacının gözetiminde sınıf ortamında öğrenciler tarafından 7-10 dakikada doldurulmuştur.

Verilerin Analizi: Araştırmadan elde edilen veriler bilgisayar ortamında değerlendirilmiştir. Sürekli değişkenlerin normal dağılıp dağılmadığı Shapiro Wilks normallik testi ile analiz edilmiştir. Veriler normal dağılama uygunluk gösterdiğinden Independent Samples t testi, ve Oneway ANOVA parametrik testleri ile analiz edilmiştir. İstatistiksel anlamlılık düzeyi $\mathrm{p}<0,05$ olarak kabul edilmiştir.

\section{BULGULAR}

Araştırmaya katılan öğrencilerin yaş ortalaması 20,64 $\pm 1,73$ yıldır. Öğrencilerin \%20,9'u son sınıfta öğrenim görmekte, \%3,8'i eğitim sürecinde akrabasının yanında kalmaktadır. Öğrencilerin \%77,8'inin ebelik mesleğini isteyerek ve \%35,9'unun kolay iş bulma umuduyla bölümü seçtiği saptanmıştır.
Çalışmada öğrencilerin mezuniyetten hemen sonra \%32,9'unun kariyer olarak yüksek lisans yapmayı planladığ $1, \% 35,9$ 'unun sağlık hizmetlerinin birinci basamağında ve \%20,9'unun klinikte ebelik statüsü/ pozisyonunda çalışmayı düşündüğü saptanmıştır (Tablo 1).

Çalışmada öğrencilerin \%94,4'ünün bölümü isteyerek seçmenin öğrenme motivasyonunu, \%91,9'unun kişilik özelliklerin ve \%93,2'sinin alınan eğitimin mesleki kariyer planını etkilediği belirlenmiştir. Ayrıca \%65,8'inin meslekle ilgili yasa ve yönetmeliklerin, \%85,9'unun mesleki çalışma alanlarının ve \% 85,9'unun toplumun mesleğe bakış açısının mesleki kariyer planını etkilediği saptanmıştır (Tablo 2).

Çalışmada öğrencilerin ebelik bölümünü isteyerek seçme ile içsel ve dişsal güdülenme; kişisel özelliklerin kariyer planını etkileme durumu ile içsel ve olumsuz güdülenme; alınan eğitimin kariyer planını etkileme durumu ile içsel güdülenme; meslekle ilgili yasa ve yönetmeliklerin kariyer planını etkileme durumu ile içsel ve olumsuz güdülenme; mesleki çalışma alanlarının kariyer planını etkileme durumu ile olumsuz güdülenme; toplumun mesleğe bakışının olumsuz güdülenme; mezuniyetten hemen sonraki kariyer planı ile içsel ve dışsal güdülenme puanı arasında anlamlı ilişki bulunmuştur $(\mathrm{p}<0,05)$. Mesleki beklentilerin kariyer planını etkileme durumu ile güdülenme puanı arasında ilişki bulunmamıştır ( $>0,05)$. Ölçekten elde edilen içsel güdülenme pua$\mathrm{n}$ ı (min-max=16-55), dışsal güdülenme puanı (min$\max =11-25$ ), olumsuz güdülenme puanı (min$\max =13-40)^{\prime}$ 'dir (Tablo 3).

\section{TARTIŞMA VE SONUÇ}

Ülkemizde ebelik mesleğinin gelişimi ve statüsünün yükseltilmesi için, ebelik mesleğinin isteyerek seçilmesi oldukça önemlidir. ${ }^{10}$

$\mathrm{Bu}$ çalışmanın sonucuna göre öğrencilerin \% 77,8'inin ebelik bölümünü isteyerek, üçte birinin kolay iş bulma umuduyla bölümü seçtiği belirlenmiştir. Amanak ve ark. ${ }^{11}$ ebelik öğrencileri ile yaptıkları bir araştırmada öğrencilerin çoğunun ebelik bölümünü isteyerek tercih ettiklerini belirlemişlerdir. Farklı çalışmalarda ebelik öğrencilerinin yarısının iş bulma kolaylığı nedeni ile bölümü tercih ettiği belirtilmiştir. ${ }^{12-14}$ Sheehy ve ark. ${ }^{15}$ çalışmalarında ebelerin en fazla ailelerinin etkisiyle kariyer tercihlerini yaptıklarını belirlemişlerdir. Öğrencilerin ebelik bölümünü tercih etme nedenleri farklılaşsa da, son yıllardaki sağlık sektöründeki hızlı büyüme, iş bulma olanaklarının artması öğrencilerin ebelik mesleğini tercih etmelerine neden olmuştur. 
Dünyadaki tüm mesleklerde olduğu gibi, ebelik mesleğinde de bilimsel ve teknolojik hızlı gelişmeler bilgilerin güncellenmesini ve mesleki kariyer yapmayı gerektirmektedir. ${ }^{13,14}$

Çalışmada öğrencilerin mezuniyetten hemen sonra \%32,9'unun mesleki kariyer olarak yüksek lisans yapmayı planladığı, \%35,9'unun sağlık hizmetlerinin birinci basamağında ve \%20,9'unun sağlık hizmetlerinin diğer alanlarında ebelik statüsü/ pozisyonunda çalışmayı düşündüğü saptanmıştır (Tablo 1). Ay ve ark. ${ }^{16}$ araştırmalarında öğrencilerin yarıdan fazlasının kariyer planı olduğunu, bu öğrencilerin \%26,3'ünün yüksek lisans yapmayı, \%23,1'i ebe olarak çalışmayı düşündüklerini belirlemişlerdir. Ayrıca mesleği kendi isteği ile seçen öğrencilerle seçmeyen öğrencilerin mezuniyet sonrası kariyer planı yapmaları arasında istatistiksel olarak anlamlı ilişki bulmuşlardır. ${ }^{16}$ Yücel ve ark. ${ }^{14}$ öğrencilerin yaklaşık üçte birinin, birinci basamak sağlık kurumlarında çalışmak ve çok azının ise akademisyen olmak istediklerini belirlemişlerdir. Taşkın Yılmaz ve ark. ${ }^{10}$ çalışmalarında ebelerin yarıya yakının lisansüstü eğitim (yüksek lisans, doktora), \%36,9'unun yönetici olarak mesleki alanda ilerlemeyi planladıklarını saptamışlardır. Kozak ve Dalkıranoğlu ${ }^{17}$ bir devlet üniversitesinden mezun olan öğrencilerin kariyer algılarını araştırmış, öğrencilerin yüksek lisans yapmayı bir kariyer firsatı olarak gördüklerini bulmuştur. Dinç ve ark. ${ }^{18}$ çalışmalarında ebelik bölümü öğrencilerinin çoğunun mesleğini yapmak ya da kariyer yapmak istediklerini bulmuşlardır. Amanak ve ark. ${ }^{11}$ çalışmalarında öğrencilerin yarıya yakınının akademisyen ya da eğitimci olmak istediklerini belirlemişlerdir. Aynı çalışmada ${ }^{11}$ öğrenciler lisansüstü eğitim ve kariyer planı yapmak isteseler de ekonomik zorluklar nedeniyle hayallerini bir süre erteledikleri ya da vazgeçtiklerini belirtmişlerdir. $\mathrm{Ay}^{16}$ araştırmasında ebelik bölümü öğrencilerinin lisansüstü eğitim yapma ve akademisyen olma isteğinin yüksek olduğunu belirlemiştir. Çalışmada öğrencilerinin üçte birinin mezun olur olmaz kariyer olarak yüksek lisans yapmak istemelerinin en temel nedenleri, son yıllarda lisansüstü eğitimin popüler olması ve lisansüstü sonrası akademisyen olarak çalışmak istemelerinin etkili olduğu düşünülmüştür. Mesleki kariyer, bireylere para kazandırmanın yanında, bireylerin mesleki hedeflerini gerçekleştirmelerine olanak sağlaması açısından da önemlidir. Çalışmada, öğrencilerin \%94,4'ünün bölümü isteyerek seçmenin öğrenme motivasyonunu, \%91,9'unun kişilik özelliklerinin ve \%93,2'sinin verilen eğitimin mesleki kariyer planını etkilediği belirlenmiştir
(Tablo 2). Ay ve ark. ${ }^{16}$ çalışmalarında öğrencilerin büyük çoğunluğunun ebelik mesleğini sevmediğini ve mesleği bırakmak istediklerini bulmuşlardır. Şahin ve ark. ${ }^{19}$ çalışmasında ebelik öğrencilerinin yarıya yakının aldıkları eğitimi kısmen yeterli bulduklarını belirtmişlerdir. Yapılan başka bir çalışmada, öğrencilerin bölümlerini seçmelerindeki en etkili faktörün insanlara yardım etme, halkın sağlığını koruma ve geliştirme olduğu belirtilmiştir. ${ }^{10}$ Bacanlı ${ }^{21}$ akademik başarısını kötü algılayan öğrencilerin, kariyere karar verme güçlük puanlarını yüksek bulmuştur. Amanak ve ark. ${ }^{11}$ öğrencilerin ebelik bölümünü seçme nedenleri bilgi durumu ve ebeliği sevme durumu ile kariyer uyumluluğu arasında anlamlı ilişki bulmuşlardır. Bölümü isteyerek seçme, mesleki güdülenme ve verilen eğitim öğrencilerin kariyer planını etkilemiştir.

Bireyler, meslek seçimi yaptıklarında ve mesleki eğitimine başladıklarında meslekleri ile ilgili kariyer planları yapmaya başlamaktadır. Kariyer planlama döneminde gençler meslekleri ile ilgili hedef belirlemeye çalışırlar. ${ }^{10,22}$ Öğrencilerin \%65,8'inin meslekle ilgili yasa ve yönetmeliklerin, \%85,9'unun mesleki çalışma alanlarının ve \%85,9'unun toplumun mesleğe bakış açısının mesleki kariyer planını etkilediği saptanmıştır (Tablo 2). Taşkın Yılmaz ve ark. $^{10}$ çalışmalarında ebelerin \%36,5'inin mesleki bakış açılarının olumsuz olduğunu, çalışma koşullar1, ücret, prim gibi faktörlerin geleceğe yönelik mesleki beklentilerini ve motivasyonlarını etkilediğini vurgulamışlardır. Woeber ve Sibley ${ }^{23}$ yaptıkları çalışmada ebelerin büyük bir çoğunluğu beş yıl kadar meslekte kalabileceklerini ve çalışma saatlerinin düzenlenmesi gerektiğini bildirmişlerdir. Mesleki çalışma alanlarının ve toplumun mesleğe bakış açısının kariyer planını daha fazla etkilediği görülmüştür. Bireyin, mesleki tercihleri/seçimleri ve kariyer gelişimi genel olarak eğitim süreci içinde gerçekleşir. Çalışmada öğrencilerin ebelik bölümünü isteyerek seçme ile içsel ve dişsal güdülenme; kişisel özelliklerin kariyer planını etkileme durumu ile içsel ve olumsuz güdülenme; alınan eğitimin kariyer planını etkileme durumu ile içsel güdülenme; mesleki çalışma alanlarının kariyer planını etkileme durumu ile olumsuz güdülenme; toplumun mesleğe bakışının olumsuz güdülenme; mezuniyetten hemen sonraki kariyer planı ile içsel ve dışsal güdülenme puanı arasında anlamlı ilişki bulunmuştur (Tablo 3). Ay ve ark. $^{16}$ mesleği kendi isteği ile seçen öğrencilerin meslekle ilgili kariyer planı yapmayı düşünmeleri arasında istatistiksel açıdan anlamlı ilişki bulmuşlardır. Ertekin Pınar ve ark. ${ }^{24}$ mezun olduktan sonra 
yüksek lisans yapmak isteyen öğrencilerin içsel güdülenme puanlarının yüksek ancak, bölümü kendi isteği dışında tercih edenlerin, içsel güdülenme puan ortalamalarını daha düşük olduğunu bulmuşlardır. Bilgin ve Ocakçı ${ }^{22}$ yaptıkları çalışmada ebelik bölümünü kendi isteği ile seçen öğrencilerin daha iyi motive ve kariyer için umutlu olduklarını bulmuşlardır. Amanak ve ark. ${ }^{11}$ öğrencilerin ebeliği sevme durumu ile kariyer geleceği ölçeği toplam puan arasında ilişki bulmuşlardır. Yine bu çalışmada ${ }^{11}$ kariyer algısının ebelik mesleğini seçme ve sevme durumlarına göre değiştiği saptanmıştır. Taşkın Yı1maz ve ark. ${ }^{10}$ çalışmalarında ebe ve hemşirelerin geleceğe ilişkin kariyer beklentilerinin iyimser olduğunu belirlemişlerdir. Kinsella ve ark. ${ }^{25}$ yaptıkları çalışmada hemşirelerin kariyer planlarına yönelik motive edici durumların, lisansüstü eğitime uyum sağlamalarında etkili olduğu bulmuşlardır. İran'da yapılan bir çalışmada hemşirelerin kariyer durumunun bireysel ve çevresel faktörlerden etkilenen çok boyutlu bir süreç olduğu bulmuşlardır. ${ }^{26}$ Bengtsson ve Ohlsson ${ }^{1}$ içsel olarak motive olan öğrencilerin zevk için öğrendiklerini ve eğitimleri hakkında kendi karalarını verdiklerini belirtmişlerdir. Çalışmada, güdülenme ile ilgili sonuçlar diğer çalışma sonuçlarından biraz farklılaştığı görülmüştür. Bu farklılaşma çalışmanın örneklem kriterlerinden ve veri toplama araçlarından kaynaklanmıştır. Mesleği sevme, mesleği yapmaya istekli olma, öğrencilerin içsel güdülenme ve mesleki kariyer planlarını pozitif yönde etkilemiştir.

Mesleğin/bölümün istenerek bilinçli bir şekilde seçilmesi mesleki güdülenme ve kariyer planı açısından oldukça önemlidir. Bu araştırmanın sonuçlarına göre: Öğrencilerin çoğunluğunun mesleği isteyerek ve üçte birinin kolay iş bulma umuduyla bölümü seçtiği, üçte birinin mezuniyetten hemen sonra kariyer olarak yüksek lisans yapmayı planladı̆̆ı, az sayıdaki öğrencinin ise, sağlık bakım hizmetlerinin çeşitli alanlarında ebe olarak çalışmak istediği belirlenmiştir. Ayrıca bölümü isteyerek seçen öğrencilerin içsel güdülenme puan ortalamaları yüksek bulunmuştur. $\mathrm{Bu}$ durum öğrencilerin meslekleri ile ilgili hedeflerini ve kariyer planlarını etkilemiştir.

Sonuç olarak, ebelik mesleğinin istenerek seçilmesi içsel güdülenme ve kariyer planını pozitif yönde etkilemiştir. Ebelik mesleğinin bilimsel gelişimi ve profesyonel olarak güçlenmesi için mesleği isteyerek seçenlerin oranlarının artırılmasına yönelik planlamaların yapılması, bölümü tercih eden öğrencilerin ise, mesleki güdülenmeyi artırıcı aktivitelere katılımları için motive edilmeleri, öğrencilerin beklenti ve becerilerine yönelik kariyer planlamaları yapabilmeleri için kariyer danışmanlığı verilmesi önerilir.

Araştırmanın yalnızca bir üniversitenin ebelik bölümünde yapılmış olması ve verilerin öğrencilerin formlara vermiş oldukları cevaplarla sınırlı olması bu araştırmanın sınırlılığgdır.

Etik Komite Onayı: Çalışmamız Marmara Üniversitesi, Sağlık Bilimleri Fakültesi Üniversitesi Girişimsel Olmayan Klinik Araştırmalar Etik Kurulu (Tarih:13/12/2018, karar no:60) tarafindan onaylandi.

Çıkar Çatışması: Yazarlar çıkar çatışması bildirmemişlerdir.

Yazar Katkılart: Fikir-ZB; Denetleme-ZB; Malzemeler-ME; Veri toplanması ve işlemesi -ZB, ME; Analiz ve yorum -ZB; Yazıyı yazan-ZB.

Hakem değerlendirmesi: Dış bağımsız.

Teşekkür: Çalışmaya katılan tüm öğrencilere teşekkür ederiz.

\section{KAYNAKLAR}

1. Bengtsson M, Ohlsson B. The nursing and medical students motivation to attain knowledge. Nurse Educ Today. 2010;30(2):150-156. doi:10.1016/j.nedt.2009.07.005

2. Martin, A. School motivation of boys and girls: differences of degree, differences of kind, or both? Aust J Psychol. 2004;56(3):133-146. doi: 10.1080/00049530412331283363

3. Acat MB, Köşgeroğlu N. Güdülenme kaynakları ve sorunları ölçeği. Anadolu Psikiyatri Dergisi. 2006;7(4):204-210.

4. Cevher E. Üniversitelerde kariyer planlama faaliyetleri ekseninde kariyer merkezlerine yönelik bir araştırma. Karabük Üniversitesi Sosyal Bilimler Enstitüsü Dergisi. 2015;5(2):164-177.

5. Anafarta N. Orta düzey yöneticilerin kariye planlamasına bireysel perspektif. Akdeniz Üniversitesi İktisadi ve İdari Bilimler Fakültesi Dergisi. 2001;2(1):1-17.

6. Acar R, Özdaşlı K. Bireysel kariyer planlama yapmanın öğrenci başarısı üzerindeki etkisi: SBMYO öğrenci üzerine bir araştırma. Mehmet Akif Ersoy Üniversitesi Sosyal Bilimler Enstitüsü Dergisi. 2017;9(21):301-314.

7. Musriha, HJ, Msi DE. The impact of individual characteristics and organizational culture on performance and career development of employees 
case studies five star hotel in Surabaya Indonesia. Journal of Business and Management. 2013;14(3):21-27.

8. Kanagaraj AK, Archana S, Malathi K. A study of employees career planning and development. Global Journal for Research Analysis. 2014;3 (7):196-197.

9. Ulaş Ö, Özdemir S. Üniversite son sınıf öğrencilerinde algilanan kariyer engellerinin yorday1cıları. Hacettepe Üniversitesi Eğitim Fakültesi Dergisi. 2018;33(3):672-688. doi: 10.16986/ HUJE.2017033806

10. Taşkın Yılmaz F, Tiryaki Şen H, Demirkaya F. Hemşirelerin ve ebelerin mesleklerini algılama biçimleri ve gelecekten beklentileri. Sağlık ve Hemşirelik Yönetimi Dergisi. 2014;3(1):130139. doi:10.5222/SHYD.2014.130

11. Amanak K, Şeker S, Çitil Canbay F, Esen E. Ebelik öğrencilerinin lisansüstü eğitim ve kariyer tercihlerinin belirlenmesi: Bir karma yöntem çalışması. Düzce Üniversitesi Sağlık Bilimleri Enstitüsü Dergisi. 2020;10(1):58-67.

12. Erkal SG, Yalçın AS, Sancar B. Ankara üniversitesi sağlık bilimleri fakültesi öğrencilerinin ebelik ve hemşirelik bölümlerini seçme nedenleri. Ankara Sağlık Bilimleri Dergisi. 2012;1 (1):73-90

13. Yurtsal ZB, Biçer S, Duran Ö, Şahin A, Arslan M, Yavrucu ÖK. Sağlık bilimleri fakültesi ebelik 1. ve 4. sınıf öğrencilerinin mesleğe ilişkin görüşlerinin belirlenmesi. Erciyes Üniversitesi Sağlık Bilimleri Fakültesi Dergisi. 2014;2(2):1525.

14. Yücel U, Tuna Oran N, Yüksel E. Ebelik öğrencilerinin meslek ile ilgili görüşlerinin ve mezuniyet sonrası çalışmak istedikleri kurumların değerlendirilmesi. Gümüşhane Üniversitesi Sağlık Bilimleri Dergisi. 2017;6(4):69-76.

15. Sheehy A, Smith RM, Gray JE, Homer CSE. Midwifery pre-registration education and midcareer workforce participation and experiences. Women Birth. 2018;32(2):1-7. doi.10.1016/ j.wombi.2018.06.014

16. Ay F, Keçe M, İnci İ, Alkan N, Acar G. Ebelik öğrencilerinin meslek algıları ve kariyer planlarını etkileyen faktörler. Balıkesir Sağlık Bilimleri Dergisi. 2018;7(2):74-82. doi: 10.5505/ bsbd.2018.09815

17. Kozak MA, Dalkıranoğlu T. Mezun öğrencilerin kariyer algılamaları: Anadolu üniversitesi örneği. Anadolu Üniversitesi Sosyal Bilimler Dergisi. 2013;13(1):41-52.
18. Dinç A, Cangöl E, Söğüt S. Ebelik öğrencilerinin mesleki tercih hakkında düşünceleri. Cumhuriyet Üniversitesi Sağlık Bilimleri Enstitüsü Dergisi. 2017;2(2):15-23.

19. Şahin S, Özdemir K, Semiz O, Gültekin Z, Duman E. Ebelik öğrencilerinin ebelik mesleğine ve eğitimine ilişkin bakış açıları. II. Ulusal Ebelik Öğrenci Kongresi. 27-29 Nisan 2011, Aydın/ Türkiye.

20. Dinç A, Cangöl E, Söğüt S. Ebelik öğrencilerinin mesleki tercih hakkında düşünceleri. Cumhuriyet Üniversitesi Sağlık Bilimleri Enstitüsü Dergisi. 2017;2(2):15-23.

21. Bacanlı F. Kariyer karar verme güçlükleri ve meslek seçimine ilişkin akılcı olmayan inançların ilişkisi. Türk Psikolojik Danışma ve Rehberlik Dergisi. 2012;4(37):86-95.

22. Bilgin Z, Ocakçı AF. Ebelik öğrencilerinde mesleki güdülenme. Anadolu Hemşirelik ve Sağlık Bilimleri Dergisi. 2011;14(3):40-46.

23. Woeber K, Sibley L. The effect of prior work experiences on the preparation and employment of early-career midwives. Journal of Midwifery \& Women's Health. 2018;63(6):668-77. doi:10.1111/jmwh.12910

24. Ertekin Pınar Ş, Yıldırım G, Duran Ö, Cesur B, Üstün Z, Güler E. Ana çocuk sağlığı hizmetlerinde kilit rolde olan ebe adaylarının güdülenmeleri yeterli mi? Bir anket çalışması. Hemarge. 2014;11(3):22-31.

25. Kinsella D, Fry M, Zecchin A. Motivational factors influencing nurses to undertake postgraduate hospital-based education. Nurse Education in Practice Journal. 2018;31:54-60. doi:10.1016/j.nepr.2018.04.011

26. Zamanzadeh V, Valizadeh L, Praskova A, Ghahramanian A, Rassouli M, Asghari E. Reaching for the stars: Iranian nurses' perceptions of career success. International Nursing Review. 2019;66(1):78-86. doi:10.1111/inr.12460 
Tablo 1. Öğrencilerin mesleki kariyer planlamalarına ilişkin görüşleri.

\begin{tabular}{|c|c|c|}
\hline Mesleki Kariyere İlişskin Görüşler & Sayı & $\%$ \\
\hline \multicolumn{3}{|l|}{ Mezuniyet sonrası mesleki kariyer planı } \\
\hline Sağlık hizmetleri alanında çalışma & 127 & 54,3 \\
\hline Yüksek lisans yapma & 77 & 32,9 \\
\hline Farklı bir işte çalışma & 10 & 4,3 \\
\hline Fikri yok & 20 & 8,5 \\
\hline \multicolumn{3}{|c|}{ Mezuniyet sonrası çalışmak istediği sağlık hizmet basamağ } \\
\hline Birinci basamak & 84 & 35,9 \\
\hline İkinci basamak & 65 & 27,8 \\
\hline Üçüncü basamak & 85 & 36,3 \\
\hline \multicolumn{3}{|c|}{ Meslekte çalışmayı istediği statü/pozisyon ve alan } \\
\hline Yönetici ebe & 58 & 24,8 \\
\hline Eğitimci ebe & 79 & 33,8 \\
\hline ASM'de ebe & 48 & 20,5 \\
\hline Klinisyen ebe & 49 & 20,9 \\
\hline
\end{tabular}

ASM:Aile Sağlı̆̆ı Merkezi. 
Tablo 2. Öğrencilerin mesleki güdülenme ve kariyer planlarını etkileyen faktöre ilişkin görüşleri.

\begin{tabular}{|l|c|c|}
\hline Öğrencilerin Görüşleri & Sayı & $\%$ \\
\hline Bölümü isteyerek seçmenin öğrenme motivasyonunu etkileme durumu \\
\hline Evet & 221 & 94,4 \\
\hline Hayır & 13 & 5,6 \\
\hline Kişilik özelliklerin kariyer planını etkileme durumu \\
\hline Evet & 215 & 91,9 \\
\hline Hayır & 19 & 8,1 \\
\hline Alınan eğitimin kariyer planını etkileme durumu \\
\hline Evet & 218 & 93,2 \\
\hline Hayır & 16 & 6,8 \\
\hline Meslekle ilgili yasa ve yönetmeliklerin kariyer planını etkileme durumu \\
\hline Evet & 154 & 65,8 \\
\hline Hayır & 80 & 34,2 \\
\hline Mesleki çalışma alanlarının kariyer planını etkileme durumu \\
\hline Evet & 201 & 85,9 \\
\hline Hayır & 33 & 14,1 \\
\hline Toplumun mesleğe bakış açısının kariyer planını etkileme durumu \\
\hline Evet & 201 & 85,9 \\
\hline Hayır & 33 & 14,1 \\
\hline
\end{tabular}


Tablo 3. Öğrencilerin mesleğe ilişkin görüşlerine göre güdülenme puan ortalamaları.

\begin{tabular}{|c|c|c|c|c|c|}
\hline \multirow{3}{*}{$\begin{array}{l}\text { Öğrencilerin } \\
\text { Görüşleri }\end{array}$} & & \multicolumn{4}{|c|}{ GKSÖ } \\
\hline & & $\begin{array}{c}\text { İçsel } \\
\text { Güdülenme }\end{array}$ & $\begin{array}{c}\text { Dişsal } \\
\text { Güdülenme }\end{array}$ & $\begin{array}{c}\text { Olumsuz } \\
\text { Güdülenme }\end{array}$ & $\begin{array}{c}\text { Toplam } \\
\text { Güdülenme }\end{array}$ \\
\hline & $\mathbf{n}$ & Mean \pm SD & Mean \pm SD & Mean \pm SD & Mean \pm SD \\
\hline \multicolumn{6}{|c|}{ Bölümü isteyerek seçme } \\
\hline İsteyerek & 182 & $45,3 \pm 5,7$ & $21,9 \pm 2,7$ & $26,5 \pm 6,4$ & $93,8 \pm 10,1$ \\
\hline İstemeyerek & 52 & $33,8 \pm 7,3$ & $20,2 \pm 3,2$ & $25,9 \pm 5,4$ & $80,0 \pm 11,0$ \\
\hline $\mathrm{t} / \mathrm{p}$ & 234 & $10,485 / 0,000$ & $3,325 / 0,001$ & $0,558 / 0,578$ & $8,028 / 0,000$ \\
\hline \multicolumn{6}{|c|}{ Kişisel özelliklerin kariyer planını etkileme durumu } \\
\hline Evet & 215 & $43,1 \pm 7,6$ & $21,6 \pm 2,8$ & $26,1 \pm 6,2$ & $91,0 \pm 11,7$ \\
\hline Hayır & 19 & $38,7 \pm 8,6$ & $20,3 \pm 3,5$ & $29,3 \pm 5,7$ & $88,4 \pm 13,2$ \\
\hline $\mathrm{t} / \mathrm{p}$ & 234 & $2,142 / 0,044$ & $1,938 / 0,054$ & $2,295 / 0,032$ & $0,909 / 0,364$ \\
\hline \multicolumn{6}{|c|}{ Mesleki beklentilerin kariyer planını etkileme durumu } \\
\hline Evet & 214 & $42,5 \pm 7,7$ & $21,5 \pm 2,9$ & $26,5 \pm 6,0$ & $90,6 \pm 11,8$ \\
\hline Hayır & 20 & $45,8 \pm 7,7$ & $21,6 \pm 2,8$ & $24,7 \pm 7,9$ & $92,2 \pm 11,5$ \\
\hline $\mathrm{t} / \mathrm{p}$ & 234 & $1,824 / 0,069$ & $0,143 / 0,886$ & $1,246 / 0,214$ & $0575 / 0,566$ \\
\hline \multicolumn{6}{|c|}{ Alınan eğitimin kariyer planını etkileme durumu } \\
\hline Evet & 218 & $43,3 \pm 7,2$ & $21,5 \pm 2,8$ & $26,5 \pm 6,2$ & $91,5 \pm 11,4$ \\
\hline Hayır & 16 & $35,0 \pm 10,2$ & $21,3 \pm 3,7$ & $24,2 \pm 5,4$ & $80,6 \pm 13,1$ \\
\hline $\mathrm{t} / \mathrm{p}$ & 234 & $3,200 / 0,006$ & $0,260 / 0,795$ & $1,439 / 0,152$ & $3,210 / 0,005$ \\
\hline \multicolumn{6}{|c|}{ Meslekle ilgili yasa ve yönetmeliklerin kariyer planını etkileme durumu } \\
\hline Evet & 154 & $43,1 \pm 8,0$ & $21,6 \pm 2,9$ & $27,0 \pm 6,0$ & $91,8 \pm 12,3$ \\
\hline Hayır & 80 & $42,2 \pm 7,2$ & $21,4 \pm 2,9$ & $25,1 \pm 6,4$ & $88,8 \pm 10,6$ \\
\hline $\mathrm{t} / \mathrm{p}$ & 234 & $0,579 / 0,449$ & $0,552 / 0,581$ & $2,248 / 0,026$ & $1,839 / 0,067$ \\
\hline \multicolumn{6}{|c|}{ Mesleki çalışma alanlarının kariyer planını etkileme durumu } \\
\hline Evet & 201 & $43,2 \pm 7,4$ & $21,5 \pm 2,8$ & $26,7 \pm 6,1$ & $91,5 \pm 11,5$ \\
\hline Hayır & 33 & $40,3 \pm 9,4$ & $21,3 \pm 3,3$ & $24,1 \pm 6,2$ & $85,9 \pm 12,5$ \\
\hline $\mathrm{t} / \mathrm{p}$ & 234 & $1,969 / 0,050$ & $0,349 / 0,727$ & $2,215 / 0,032$ & $2,430 / 0,020$ \\
\hline \multicolumn{6}{|c|}{ Toplumun mesleğe bakışının kariyer planını etkileme durumu } \\
\hline Evet & 201 & $42,7 \pm 7,8$ & $21,6 \pm 2,9$ & $26,8 \pm 5,9$ & $91,1 \pm 12,1$ \\
\hline Hayır & 33 & $43,4 \pm 7,3$ & $21,2 \pm 2,5$ & $23,8 \pm 7,2$ & $88,4 \pm 9,7$ \\
\hline $\mathrm{t} / \mathrm{p}$ & 234 & $0,476 / 0,635$ & $0,773 / 0,464$ & $2,232 / 0,031$ & $1,208 / 0,228$ \\
\hline \multicolumn{6}{|c|}{ Mezuniyetten hemen sonraki kariyer planı } \\
\hline $\begin{array}{l}\text { Mesleki alan- } \\
\text { da çalışma }\end{array}$ & 127 & $44,4 \pm 6,6$ & $21,8 \pm 2,5$ & $26,2 \pm 6,0$ & $92,4 \pm 9,7$ \\
\hline $\begin{array}{l}\text { Yüksek li- } \\
\text { sans yapma }\end{array}$ & 77 & $44,1 \pm 6,4$ & $22,0 \pm 2,7$ & $26,9 \pm 6,6$ & $93,1 \pm 11,3$ \\
\hline $\begin{array}{l}\text { Meslek diş1 } \\
\text { işte çalışma }\end{array}$ & 10 & $29,6 \pm 10,3$ & $16,5 \pm 3,7$ & $23,7 \pm 5,4$ & $69,8 \pm 13,6$ \\
\hline Fikri yok & 20 & $34,4 \pm 6,4$ & $20,2 \pm 3,0$ & $26,7 \pm 5,6$ & $81,4 \pm 10,7$ \\
\hline $\mathrm{t} / \mathrm{p}$ & 234 & 26,093/0,000 & $14,767 / 0,000$ & $0,914 / 0,435$ & $20,769 / 0,000$ \\
\hline
\end{tabular}

GKSÖ: Güdülenme Kaynakları ve Sorunları Ölçeği. 